\title{
Agricultural Credit Utilization among Small Scale Women Farmers in Selected Wards Of Bida Local Government Area Of Niger State, Nigeria
}

\author{
Gana, F. S., Tsado. J. H, Kenchi S. and Olaleye R. \\ Department of Agricultural Economics And Extension Technology \\ Federal University of Technology, P. M. B. 65, Minna \\ Email: francisgana2004@yahoo.com
}

\begin{abstract}
The study investigated agricultural credit utilization among small-scale women farmers in selected wards of Bida Local Government Area of Niger State. The specific objectives were to: identify the major sources of credit to small-scale farmers ; and determine the benefit (if any) which small-scale women farmers had derived after acquiring credit for their farm operations. Data were collected from one hundred respondents randomly selected from five wards with the aid of structured interview schedule. Statistical tools used for data analysis were frequency distribution, percentage and student t-test. Up to fifty-six percent of the respondents claimed that they obtained their credit from various sources for their farm operations. The results showed that $t$-calculated (17.581) was greater than t-critical (1.9842) at 1\% level of significance. Similarly, a total of $47.0 \%$ of the respondents opined that their farm produce increased their income which ranged between N31,000 - N40,000 after acquiring credit from the Cooperative Bank. It was concluded that small-scale women farmers' income increased when they had access to credit facilities from banks. Therefore, it was recommended that the regulatory body responsible to oversee the activities of (NACRDB) monitor regularly the disbursement of agricultural loan to women farmers at the appropriate planning season with reasonable interest charge and that extension agents should ensure that the loan is utilized for only agricultural purposes.
\end{abstract}

Key words: Credit utilization, small-scale farmer's income generation, Niger State.

\section{INTRODUCTION}

Agriculture has been the most important sector of Nigerian economy. It employs about $80 \%$ of the adult working population and earns about $60 \%$ of the Gross Domestic Product (GDP) of Nigerian economy (International Food, 2006) This is one of the reasons why the country's economic development policy has been based on the expansion of peasant agricultural production Olayemi (1980). Manfred et al(1997) reported that the major constraint to small-scale farmers improving their farm operations was largely due to restrictions to access credit facilities Sadoulet and January (1995), suggested that farm credit is not only necessitated by limitations of self-finance, but also by uncertainties pertaining to the level of output and time lag between input and output. It is from the realization of this critical nature of agriculture that the Federal 
Journal of Agricultural Extension

Vol. 13 (2) December 2009

Government has come up with the strategy of transforming the economy on improving the rural agriculture. One of the measures is the establishment of the Nigerian Agricultural, Cooperative and Rural Development Bank (NACRDB, 2000), the single largest agricultural development finance institution in Nigeria. (NACRDB) is one of the efforts of the Federal Government of Nigeria aimed at boosting the delivery of agricultural, macro and micro credit, to improve agricultural development thereby alleviating poverty among the rural and urban poor Nigerians. Small-scale women farmers who participate with their husbands or those that are on their on in crop farming are also involved in processing, storage, and marketing These women are faced with enormous difficulties in acquiring credit facilities such as late disbursement of agricultural loans, non-fulfillment of security collateral requirement, diversification of funds by the bank management for non-agricultural purposes and inability of the bank to reach small-scale women farmers at the grass root. One of the major constraints small-scale women farmers are facing in Nigeria is that of inability to access credit facilities for agricultural production. It is envisaged that when these conditions are improved upon that the value of small-scale women farmers' income will meet their expectations that will create enabling environment for the development of economic base of low income women farmers. The general objective of the study therefore is to examine agricultural credit utilization among small-scale women farmers in Bida Local Government Area of Niger State, Nigeria.

The specific objectives are: (i) to identify the major sources of credit to small-scale farmers and (ii) to examine the benefit if (any) small-scale women farmers had derived from the credit which they (farmers) had obtained for farm operations.

\section{METHODOLOGY}

\section{Area of study}

This study was conducted in Bida Local Government Area of Niger State. The state lies between $3^{0}-20$ East and longitude $8^{0}$ and $11^{0}-3$ North. The State is bordered to the North by Sokoto State, to Northwest by Kebbi State, to the South by Kogi, to the Southwest by Kwara State, while Kaduna and Federal capital territory border the state to the Northeast and Southeast respectively.

Furthermore, the state has a common international boundary with the republic of Benin at Babanna in Borgu Local Government Area of Niger State. The state covers a total land area of $83,266,779$ square kilometer or about 8.3 million hectares, which represents $8 \%$ of arable land.

About $85 \%$ of the populations are farmers while the remaining $15 \%$ engage in other vocations such as white collar jobs, manufacturing, and business among others. The women farmers cultivate crops like guinea corn, maize, millet, cow tree, cassava, vegetables to mention a few. They equally engage in storage, marketing processing of she abutter, rice, groundnut, and cassava. The population of the state according to census figure was about 3,950,249 (NPC, 2006). Niger State is referred to as the "Power" state of the nation because; it houses three hydro electric power stations. They are the Shiroro Hydro-Electric power station, Kanji generating plant and the Jebba Hydro Electric Dam.

The area where this research study was conducted is Bida Local Government Area of Niger State. Bida Local Government is divided into two constituencies namely; Bida North and

Bida South. The dominant populations living in that area are the Nupe speaking community with very few other community groups. The project was carried out within 11 months, from January to November, 2008. 


\section{Sampling procedure and sampling size}

Purposely random sampling technique was used in this study. This was to ensure that a good number of small scale women farmers who had access to credit loan in the five(5) selected wards of Bida Local Government Area of Niger State were well represented. These wards included the following: Bida North constituency, having wadata ward, Masaba A ward, Masaba B ward, while Bida South constituency consists of Dokodza ward and Ndajiya wards respectively.

Total number of farmers in the five selected wards was 234; that is Masaba Ward 30 , Masaba Ward A 40, Masaba Ward B 50, Dokoza 54, and Ndajiya 60 respectively.

\section{Names of Wards}

For Masaba Ward

For Masaba A

For Masaba B

For Dokoza

For Ndajiya

\section{Number of respondents selected}

$\begin{array}{lllll}\frac{30}{234} & \times \frac{100}{1} & & 13 \% \\ \frac{40}{234} & \times \quad \frac{100}{1} & & \\ \frac{50}{234} & \times & \frac{100}{1} & & 17 \% \\ \frac{54}{234} & \times & \frac{100}{1} & & 21 \% \\ \frac{60}{234} & \times & \frac{100}{1} & = & 23 \% \\ & & = & 100\end{array}$

\section{Measurement of variables}

The socio-economic characteristics of the women farmers included: Age of the women farmers sampled, their farm sizes, their educational attainment, their house hold sizes, and their farming experiences. The age of the farmer is age at the time of survey; level of education, is the number of years of formal education the women farmers had, while household size was the number of people eating from the same pot.

The farm size is measured in hectares while the farming experience is the number of years the farmer had been farming.

The income of small-scale women farmers is the amount realized from their farming after acquisition of credit facilities.

\section{Method of data collection}

The primary data were obtained through the administration of an interview schedule Secondary data were collected from published and unpublished reports. All the one hundred interview schedule were returned and used for analysis.

\section{Analytical techniques}

Tools for analysis such as frequency tables and percentage were used to test the sampling units. Descriptive statistics such as t-test was also used to establish the relationships which existed in the group of sampling units. 
Journal of Agricultural Extension

Vol. 13 (2) December 2009

\section{RESULTS AND DISCUSSION}

\section{Socio-Economic Characteristics of Participating Women Farmers ( $N=100)$}

Table 1 reveals that (46.0\%) of the respondents are within the age range of 31-40 years. A total of $(26 \%)$ said that they were within the ages of $21-30$ years. while $(14 \%)$ of the respondents claimed that they were below 20 years of age and $(12 \%)$ of the respondents were found to belong to the range of 41-50 years of age. Only (2\%) of the respondents said that they were within the age range of 51-60 years. These results showed that credit are given to about $40 \%$ young farmers below 30 years who are willing and ready to work on the farm.

TABLE 1: Percentage distribution of the age of the respondents

\begin{tabular}{lcc}
\hline Age (Years) & Frequency & Percentage \\
\hline$<20$ & 14 & 14.00 \\
$21-30$ & 26 & 26.00 \\
$31-40$ & 46 & 46.00 \\
$41-50$ & 12 & 12.00 \\
$51-60$ & 2 & 2.00 \\
60 and above & 0 & 0 \\
\hline Total & $\mathbf{1 0 0}$ & $\mathbf{1 0 0}$ \\
\hline
\end{tabular}

Source: Field Survey, 2008

From Table 2, it is revealed that the greater proportion of the sampled farmers $(54 \%)$ claimed that they had no formal education while $(31 \%)$ said that they had obtained primary school education. About (13\%) of the respondents had obtained secondary education and only $(2 \%)$ of the sample farmers said that they had obtained tertiary education. However, the educational level of small - scale women farmer contributed to the level of production in terms of adoption of new technologies and the ways which inputs should be used on the farm to enhance greater output and farmers' entrepreneurial ability.

Apata (1991) reported that educational level determines the quality of skills of farmers, technical competence and how likely it is for him/her to acquire agricultural credit and put into proper usage for better returns. 
TABLE 2: Educational Attainment of Respondents

\begin{tabular}{lcc}
\hline Educational Attainment & Frequency & Percentage \\
\hline No formal Education & 54 & 54 \\
Primary Education & 31 & 31 \\
Secondary Education & 13 & 13 \\
Tertiary Education & 2 & $\mathbf{2}$ \\
\hline Total & $\mathbf{1 0 0}$ & $\mathbf{1 0 0}$ \\
\hline
\end{tabular}

Source: Field Survey, 2008

Table 3 shows that majority of the respondents (56\%) sourced their credit from cooperative society while $(24 \%)$ said that they sourced their credit from Nigeria Agricultural Cooperatives and Rural Development Bank (NACRDB) and (11\%) said they sourced theirs from individual contribution. Some claimed they sourced their credit from friends and relatives having a total of $(7 \%)$ and only two percent $(2 \%)$ claimed that they obtained there's form commercial bank. This might be due to the problem encountered during loan acquisition from NACRDB such as problem of guarantors and collaterals offered, problem of interest charges by the Commercial Banks that is why most of them source and believed with their contributions (Adashi) and cooperative society association due to very low or no interest rate charged; and flexibility in loan repayment. Ndamitsa (2004) reported that credit has for a long time been accorded or given a place of prominence in agricultural development efforts. Farmers need to borrow capital to finance agricultural production by purchasing improved variety of seeds fertilizer, agro-chemicals and to hire labour.

TABLE 3: Sources Obtained by Respondents

\begin{tabular}{lcl}
\hline Source & Frequency & Percentage \\
\hline Friends/Relatives & 7 & 7 \\
Commercial Banks & 2 & 2 \\
NACRDB & 24 & 24 \\
Cooperative Society & 56 & 56 \\
Contribution & 11 & 11 \\
\hline Total & $\mathbf{1 0 0}$ & $\mathbf{1 0 0}$ \\
\hline
\end{tabular}

Source: Field Survey, 2008

Table 4 reveals that, eighteen percent (18\%) of the respondents said that extension workers helped to inform them about the source of credit while fifteen percent $(15 \%)$ claimed that the extension agents linked the respondents to sources of credit for example the NACRDB, NAIC among others. 
Journal of Agricultural Extension

Vol. 13 (2) December 2009

The highest population of respondents $55 \%$ claimed that extension services were not provided to them. This may be due to the effects that extension personnel scheduling meetings were not convenient to extension work because the respondents were all female.

TABLE 4: Extension Agents' Intervention in Credit Acquisition by Respondents

\begin{tabular}{lcc} 
Source & Frequency & Percentage \\
\hline inform farmers about credit source & 18 & 18 \\
Link the with credit source & 15 & 15 \\
Help in acquiring credit & 2 & 2 \\
Non of the above & 55 & 55 \\
\hline \multicolumn{1}{c}{ Total } & 100 & 100 \\
\hline
\end{tabular}

Source: Field Survey, 2008

From Table 5, it was reveled that, the greater number of respondents said that before the loan disbursement their income was found to be very low.

Sixty three percent $(63 \%)$ of the Respondents said they were within the range of $\$ 10,000$ and $\$ 20,000$, while twenty seven (27\%) claimed that their income range fell between $\$ 21,00$ and $\$ 30,00$ annually and $(6 \%)$ said their was between $\$ 31,000$ and $\$ 40,000$ and four percent (4\%) between the range of $\$ 41,000$ and $\$ 50,000$ annually. None of them agreed to say their income annually was up to $\mathrm{A50,00}$ and above.

TABLE 5: Initial Income of Farmers before Credit Acquisition by Respondents

\begin{tabular}{lcc}
\hline Income $\mathbf{( N )}$ & Frequency & Percentage \\
\hline $10,000-20,000$ & 63 & 63 \\
$21,000-30,000$ & 27 & 27 \\
$31,000-40,000$ & 6 & 6 \\
$41,000-50,000$ & 4 & 4 \\
51,000 and above & 0 & 0 \\
\hline Total & 100 & 100 \\
\hline
\end{tabular}

Source: Field Survey, 2008 
TABLE 6: Income after Acquisition by Respondents

\begin{tabular}{lll}
\hline Output $(\mathbf{N})$ & Frequency & Percentage \\
\hline $10,000-20,000$ & 21 & 21 \\
$21,000-30,000$ & 16 & 16 \\
$31,000-40,000$ & 47 & 47 \\
$41,000-50,000$ & 6 & 6 \\
51,000 and above & 10 & 10 \\
\hline Total & $\mathbf{1 0 0}$ & $\mathbf{1 0 0}$ \\
\hline
\end{tabular}

Source: Field Survey, 2008

TABLE 7: Student t-test analysis indicating income of respondents before and after credit acquisition

Pair mean student deviation T.D.sig (2tailed)

Income before $\quad 90050 \quad 5,219941 \quad 17,581$

The credit and after

Source Field survey, 2008

Significant at 0.01

The result from Table 7 reveals that there is significant relationship between the income of farmers before the credit acquisition and after $t$. calculated $(17,581)$ is greater than $t(1.9842)$ critical at $1 \%$ level of significant.

\section{CONCLUSION AND RECOMMENDATIONS}

Based on the findings it can be concluded that small-scale farmers who had access to credit facilities benefited from the loan given to them inform of increased income. Considering the foregoing, therefore it is recommended (i) That small-scale farmers should be encouraged to form economic groups like cooperative society and economic interest associations to enable them enjoy group loans that reduces bank administrative cost of loans. (ii) Government should encourage Bank to disburse agricultural loan to small-scale farmers at appropriate time of farm operations. (iii) International Finance Organizations and NGOs that seek to promote empowerment of rural communities should encourage rural micro financing to reduce or eliminate poverty especially women among the rural communities in Nigeria. (iv) women extension agents should be trained adequately in order to assist small-scale women farmers to secure loans from financial institutions. 
Journal of Agricultural Extension

Vol. 13 (2) December 2009

\section{REFERENCES}

Apata T. C. (1991) "Effects of credit in small-scale farming" A case study of Akure and lkole. Published by Department of Agricultural Economics and Extension Technology. Federal University of Technology, Akure pp . 25-26.

Manfred,Z. Gertrud S, Joachimvom B and Franz, H. (i997) "Rural Financer Food Security for the Poor " $\mathrm{pp}$. 1-12

Ndanitsa, M. A. (2002) “ Agricultural Finance Manual.” Published in 2004 by Department of Agricultural Economics and Extension Technology. Federal University of Technology Minna.

(NACRBD, 2000), Nigeria Agricultural Cooperative and Rural Development Bank Limited. Publication of NACRBD 2009.

(NPC, 2006) National Population Commission.

International Food.(2006) International Food; Policy Research Institute From " Best Practice " To Best Fit" A Framework For Analyzing Pluralistic Agricultural Advisory Services Worldwide Washington. D.C 2006-2002 USA.

Olayemi, J. K (1980) "Food Crop Production by Small-scale Farmers in Nigeria. Problems and Prospects in integrated Rural Development. Published by University of Ibadan pp. 18-33

Sodoulet and A January,(1995 ) Quantitative Development Policy Analysis .The John's Hopkins University Press. Baltimore and London.

Swanson, B E Farner B. J. Bahal R. (1990) The Current Status of Agricultural Extension World wide in: FAO: Report of the Global Consultation on Agricultural Extension, Rome, Italy, 4-8 December 1989, Rome: Food and Agriculture Organization. 